\title{
Individual Innovativeness of Different Generations in the Context of the Forthcoming Society 5.0 in Lithuania
}

\author{
Asta Savaneviciene, Gita Statnicke, Sigitas Vaitkevicius
}

\author{
Kaunas University of Technology \\ K. Donelaicio st. 73, LT-44029, Kaunas, Lithuania \\ E-mail.asta.savaneviciene@ktu.lt, gita.statnicke@ktu.edu, sigitas.vaitkevicius@ktu.lt
}

cross $^{\text {ref }}$ http://dx.doi.org/10.5755/j01.ee.30.2.22760

\begin{abstract}
Global challenges such as climate change, the depletion of natural resources, rising economic disparities, and aging society are increasingly encountered in the world. The initiative Society 5.0 aims are to solve these problems and create the Super Smart Society, when innovation brings together the virtual world and reality. Given the aging issues in Lithuania, the development of the Society 5.0 is a challenge for the country today. Therefore, it is very important to consider how representatives from different generations can contribute to the creation of the Society 5.0, also called the Super Smart Society, in Lithuania. The purpose of the paper is to disclose the individual innovativeness of different generations in the context of the forthcoming Society 5.0 in Lithuania. The paper provides the generation conception, gives a short overview of generational diversity, focuses on generational differences, discusses theoretical aspects of individual innovativeness, and provides the empirical results of individual innovativeness of different generations in Lithuania: the Baby Boomers, the Generation $X$, the Generation $Y$ and the Generation Z. Finally, based on the findings, the discussion considering the contribution of different generations to creation of the Society 5.0 in Lithuania is provided. A quantitative research was performed, using "Individual Innovativeness Scale" developed by Hurt, Joseph and, Cook (1977). Three methods were used for data analysis: The Hierarchical Cluster analysis, Multidimensional scaling (ALSCAL) and the CATREG - Regression for Categorical Data.
\end{abstract}

Keywords: Society 5.0; Generation; the Baby Boomers; the Generation X; the Generation Y; the Generation Z; Individual Innovativeness.

\section{Introduction}

The digitalisation of industry and social infrastructures is performed based on innovations and this process is accelerating throughout the world. Digital transformation becomes a pillar of industrial policy (Europe - Industry 4.0, Asia - Smart Cities; China - Made in China 2025, Japan Society 5.0, North America - Industrial Internet). And, although Society 5.0 has originated in Japan, its purpose is not limited just to the prosperity of one country. The frameworks and technology developed here will undoubtedly contribute to resolving societal challenges worldwide (Fukuyama, 2018). The issues facing Japan such as population aging, declining birth rates, declining population, aging infrastructure, etc. are the challenges that many other countries will be faced soon as well. As a result, Japan is one of the first countries to look for essential early solutions to this kind of problem through Society 5.0 and is already sharing its solutions with the world, helping to address similar challenges around the world. Given the fast aging issue in Lithuania, in the future this trend will be faster than in many other EU countries, therefore the development of the Society 5.0 is a challenge for Lithuania today.

In order to take over Japan's experience, the 9th EUJapan Science Policy Forum was held in 2018. One of the goals of this forum is to foster a fundamental transformation of society through the ambitious society 5.0 concept. In turn, Lithuania, as one of the EU members, has also prepared the National Progress Strategy 2030 'Lithuania 2030' (2012), which seeks to "strengthen the basic public capacity for ensuring harmonious state development and helping to respond to global economic and environmental changes in pressure from the global competition" (Lithuania's Progress Strategy 'Lithuania 2030', 2012).

The initiative Society 5.0 aims to solve these problems and create the Super Smart Society - a sustainable society in which diverse values are linked through Cyber-Physical systems (CPS), so that individuals of different generations would be able to live safely and comfortably (Shiroishi et al., 2018). Regardless of region, age, gender, language, etc. various needs of people will be considered, when creating innovative necessary things and services (Fukuyama, 2018) and, in addition, innovation brings together the virtual world and reality. In this context, individual innovativeness is an important precondition for the development of Society 5.0 in a long-term perspective. Moreover, for the successful creation of the Super Smart Society, the contribution of each generation of society is important to the development, implementation and use of innovation.

There are four different generations in the labour market: the Baby Boom Generation, the Generation X, the Generation Y and the Generation Z (Nichols \& Wright, 2018). Nowadays, more than ever, advances through innovations in science and technology are contributing to improvements in business and society (Harayama, 2017). Although scientists (Ionescu \& Dumitru, 2015; Distanont \& Khongmalai, 2018) agree that innovation is a critical factor in creating and maintaining organisational competitiveness, 
and when creating the Society 5.0, innovations are a key factor, but the major part of research works analysing individual innovativeness are devoted for determining the individual innovativeness level of the representatives of separate professions or groups (Alsos et al., 2013; Yuksel, 2015), and for analysing the innovative behaviour of the representatives of different generations (Yigit \& Aksay, 2015). However, there is a lack of research works which would cover the analysis of all the currently existing different generations in the labour market through the prism of individual innovativeness in the context of the forthcoming Society 5.0.

Because the difference in the aging process includes biophysical, psychological, and social aging due to different life circumstances (Moschis et al., 2011), these factors of different cohort groups might influence people's responses to innovativeness (Hur et al., 2017). In order to make the best use of generational differences, it is important to find out whether there is a difference in individual innovation between generations, because individuals who possess individual innovativeness can be freer, more responsible in moral terms and more mature when they look for more autonomy (Ikiz \& Asici 2017).

The purpose of the paper is to disclose the individual innovativeness in different generations in the context of the forthcoming Society 5.0 in Lithuania. This paper, applying the cohort perspective, which views generations simply as collections of people born in a given period of time, analyses individual innovativeness of generational diversity in the context of the Society 5.0, i.e. individual innovativeness among the representatives of four generations (the Baby Boomers, the Generation $\mathrm{X}$, the Generation $\mathrm{Y}$ and the Generation $\mathrm{Z}$ ), and tries to look into the differences between belonging to different generations and individual innovativeness in the context of the Society 5.0.

\section{The Context of the Society $\mathbf{5 . 0}$}

The whole world is in a new era, in which globalisation and rapid evolution of digital technologies, such as the Internet of Things (IoT), Big Data, artificial intelligence (AI) and robotics, lead to major changes in society. According to Keidanren Annual Report 2018, "Society 5.0 is the super-smart society - the fifth society in the history of human social development following on from the huntergatherer society, agrarian society, industrial society, and information society" (p. 4), and the Japanese society, which is ready to move to the next stage of evolution, is the most active today, in which the real world will be much closer to the virtual world than it is now. According to Japan Business Federation (2016), Society 5.0 is a Japanese initiative to integrate Cyber-Physical systems (CPS) with the Internet of Things (IoT), big data technologies, and artificial intelligence (AI) into every industry and all aspects of society to address societal challenges. High-priority applications are in healthcare, transportation and mobility, infrastructure maintenance, and the financial sector (Serpanos, 2018). The aim of Society 5.0 is to solve many of today's challenges in order to digitise in all levels and areas of the Japanese society and in the face of digital transformation of society itself. In essence, what Japan is doing, is the dimension of digitisation and transformation, which is now taking place, for example, in Europe, mainly at the level of individual organisations and sections of society, up to the level of full national transformation strategy, policy and even philosophy.

The Society 5.0 is also a very important aspiration for Europe. According to Levy and Wong (2014), smart society is "one that successfully harnesses the potential of digital technology and connected devices and the use of digital networks to improve people's lives" (p. 1). The information society is gradually being replaced by a smart society, in which technological advances are consistently aligned with people and their needs. Creating innovations today cannot be achieved without interdisciplinary thinking, but in terms of creation of the Society 5.0, the challenges of digital transformation can be met only through close cooperation in the fields of politics, economics and science (Pirvu \& Zamfirescu, 2017). The Society 5.0 focuses on humankind (Harayama, 2017), while economic progress in it is combined with the solution of social problems, while integrating the internet space with physical space (Shiroishi et al., 2018; Fukuyama, 2018), giving everyone the opportunity to enjoy an active and comfortable life, receiving the highest quality services regardless of age, gender, region, language, etc. (Harayama, 2017), i.e. when creating a global future through the Super Smart Society (Shiroishi et al., 2018). According to Sjodin et al. (2018), the development of novel digital technologies, connected to the Internet of Things, along with advancements in artificial intelligence and automation, is enabling a new wave of innovation. In this new wave of innovation, management is distinguished across four dimensions: strategy, people, technology, and process integration (Blackburn et al., 2017). According to Hayashi (2017), achieving such a Society 5.0 naturally requires the foundation of technologies based on materials and electronic circuits including enabling processes, namely, fundamental material technologies, meanwhile, one of the key factors in the innovation generation process is individual innovativeness. In terms of the Society 5.0, EIT Digital (2017) is a leading European digital innovation and entrepreneurial education organisation, driving Europe's digital transformation, and providing such directions of innovation development as digital industry, digital cities, digital wellbeing, digital infrastructure and digital finance.

To sum up, two reasons are behind Society 5.0: the needs of an aging society (Shiroishi et al., 2018) and the technological potential to enable those needs to be met (Fukuyama, 2018). Aging tendency is evident especially in Europe and North America, which countries face the retiring of the Baby Boomers generation (Aaltio et al., 2016). The percentage of aged people is growing rapidly worldwide and, according to EUROSTAT (2018) report, those aged 65year or over will account for $29.1 \%$ of the EU-28's $30 \%$ for population by 2080 , compared with $19.4 \%$ in 2017 . In Lithuania the population aged 65 years or over between 2007 and 2017 increased by 2,7 percent. This is more than the European (EU 28) average (2.4\%). Therefore, it can be assumed that in the future this trend will be faster than in many other EU countries. Given the aging issue in Lithuania, the development of the Society 5.0 is a challenge for Lithuania today. In 2018, Lithuania was ranked the 13th out of the 28 EU Member States in the Digital Economy and 
Society Index (DESI). Lithuania's DESI score is above the EU average and over the last year the country has progressed at the same pace as the EU. Lithuania performs particularly well in terms of Connectivity and the Integration of Digital Technology. Moreover, Lithuania has the fastest public $\mathrm{WiFi}$, which is very important to meet the needs of an aging society (Neves \& Vetere, 2019). Thus, the forthcoming Society 5.0 in Lithuania is driven by both objective reasons such as aging society and IT-based technology potential, enabling response of the demand of aging society.

\section{The Theoretical Aspects of Individual Innovativeness}

One of the key factors in the formation process of the Society 5.0 is individual innovativeness, because "recognition of innovativeness strengthens and motivates innovators to come up with more creative approaches to solving real societal problems such as unemployment, poverty, infrastructure issues, health issues and other myriad problems facing a country" (Agolla, 2018, p. 51). According to Kilicer, Bardakci and Arpaci (2018), there are numerous studies focused individual innovativeness as a variable across different disciplines (Lu et al., 2005), the adoption of technological products at different levels (Van Rijnsoever et al., 2009), the adoption of wireless mobile data services ( $\mathrm{Lu}$ et al., 2008), the effect of technology on innovativeness (Huang et al., 2009), and the effect of individual innovativeness on the adoption of new technologies (Jackson et al., 2013). There is a lack of papers in scientific literature that would link generations, individual innovativeness and the Society 5.0; meanwhile, this research is an attempt to analyse what is the relationship between different generations and individual innovation in the context of the forthcoming Society 5.0. Empirically verified knowledge of innovativeness of different generations would allow for a better understanding of the potential of innovativeness in society as well as its nature by evaluating the changes of generations structures over time. Generations change every twenty years, and with an increase in the life span of an individual, not only the problem of the aging society but also of the generational diversity in the context of individual innovativeness becomes obvious.

Individual innovativeness is inseparable from the concept of innovation. Innovation is about creating the enabling environment to generate an ongoing stream of ideas. If individuals have the capacity, the support and the power to think in a novel way, they will continue to explore. The minor personal initiatives can lead to major initiatives involving other members of organisation (Mitleton-Kelly, 2003). Martins (2018) compares the innovativeness of an individual to other members of a system.

Individual innovativeness can be defined as developing, adopting or implementing an innovation (Yuan \& Woodman, 2010). Literature demonstrates the direct positive relationship between personal values and individual innovativeness (Hartman \& Samra, 2008; Thakur et al., 2016). Individual innovativeness is defined as a risk-taking propensity that exhibits in certain individuals and these individuals are willing to take chances and to try new things and can cope with high levels of uncertainty (Leonard-
Barton \& Deschamps, 1988). Rogers (2010) distinguished five categories of individual innovativeness: innovators (who like risk and innovation); early adopters (who are easily influenced by leaders and bring innovation to the public); early majority (who consciously avoid risk and like security), late majority (who change something in their life with difficulties and take innovation unwillingly); and laggards (who do not change anything or even resist changes) (Soffer et al., 2010; Jin, 2013). The importance of innovation for organisational success has been increasingly noted in the scientific literature of the organisational sciences (Agars et al., 2008; Anderson et al., 2004). The findings of Yi, Fiedler and Park's (2006) study clearly demonstrate the powerful role individual innovativeness plays in determining user perceptions of innovation. Therefore, it is important to seek to clearly identify the behaviours, attitudes and individual innovativeness of the generations to better understand how to engage them to the workplace (Nichols \& Wright, 2018).

Summing up, one can assume that the major part of research works analysing individual innovativeness, are devoted for determining the individual innovativeness of the representatives of separate professions or groups, and for analysing the innovative behaviour of the representatives of different generations; however, there is a lack of research works, which would cover the analysis of all the currently existing different generations in the labour market through the prism of individual innovativeness.

\section{Rethinking on Generational Diversity in the Context of Individual Innovativeness}

In the scientific literature dealing with generational differences two approaches are distinguished. Some scientists have argued that the magnitude and importance of generational differences is overstated in research (Costanza et al., 2012; Trzesniewski \& Donnellan, 2010), that they are more myth than reality (Giancola, 2006) and observed generational differences may be explained, at least in part, by age, life-stage related issues, or career stage effects instead of generation (Becton et al., 2014). According to second approach, generational studies have a long and distinguished place in the social sciences, and scholars have attempted to search for the unique and distinctive characteristics of generations (Srinivasan, 2012) and studies have examined generational differences in personality differences (Goncalves, 2015), work values and attitudes (Twenge et al., 2010; Goncalves, 2015), career patterns (Lyons et al., 2015), motivation (Goncalves, 2015), worklife balance (Caesar \& Fei, 2018), learning styles (Hillman, 2014); beliefs about career success and satisfaction (Dries et al., 2008); leadership (Rudolph et al., 2018). Considering these contradictory findings, there exists a great discussion of controversy about whether or not generational differences exist (Roberts et al., 2010), with some suggesting there is no unambiguous answer because the problem of generational differences is multifaceted. This paper follows the second approach that there are generational differences and based on this approach Hansen and Leuty (2012) claim that values which persist throughout life are formed yet in childhood. For their part, values are shaped by the social, economic, political and cultural events of life (Macky et al., 2008). 
There are some researchers who emphasise that the change in values is not related to the fact that young people get older (Inglehart, 2008) and it is unlikely that this will change with advancing age (Pyoria et al., 2017). This creates a presumption that although with the age human expectations change due to different objective conditions, nevertheless the system of values remains the same.

A generation can be defined as a group of individuals born within the same historical and socio-cultural context, who experience the same formative experiences and develop unifying commonalities as a result (Mannheim, 1952). Generations are characterised by groups of people within a specific time span (Lewis, 2015). According to the Theory of Generations, the generations include individuals who were born over the same period and share social and historical events (Grodent \& Peere, 2013). Although the term generation is most accurately used to describe genealogical kinship, it has been adopted into common use to describe broader social trends (Joshi et al., 2011).

Today's workforce consists of individuals from four generations: the Silent Generation (born 1925-1945), the Baby Boomers (born 1946-1964), the Generation X (born 1965-1981), and the Generation Y (born 1982-1999); the Generation Z (born after 2000) (Twenge et al., 2010; Deyoe \& Fox, 2012). The Silent Generation has practically abandoned the labour market, so it is relevant to consider only the Baby Boom Generation, the Generation X, the Generation $\mathrm{Y}$ and the Generation $\mathrm{Z}$. The four generations thus would attach different value to work, private life, leisure, family life, social life, political commitment, gender equality, etc. (Twenge et al., 2010; Grodent \& Peere, 2013).

Arsenault (2004) emphasises the generational diversity in the labour market as well as multifaceted creativity and innovation as an opportunity for organisations to remain competitive. Skiba and Barton (2006) highlighted the millennials' multi-tasking ability and propensity for innovation fuelled by curiosity, discovery, and exploration as contributing factors of the millennial generation's active learning style (Farrell \& Hurt, 2014). The differences observed between generations can also be attributed to career stages (Twenge $e t$ al., 2010), lifecycles (Lyons et al., 2015) or age (Grodent \& Peere, 2013). The Generation Y has grown up within the technology era, using a variety of social networking sites as a main source of communication, which is different from the previous generation's face-to-face way of socialising (Twenge et al., 2010; Dent et al., 2011). Currently, scholars analyse the characteristics of the Generation Z, which is inseparable from the latest technologies, and suggest that a more detailed analysis allows defining the following tendencies: an increase in hyperactivity, infantilism, social autism, consumerism, multimedia literacy, "loop" reading, lack of communication as well as lack of analytical and critical evaluation of a text and its meaningful rendering (Geck, 2007; Carrington et al., 2015).

Many scholars agree that there are differences between the generations in work values, attitudes and preferences. Looking from the cohort perspective, which views that the generations are different, and taking into consideration the innovation diffusion theory (Rogers, 2010), which views that individuals react differently to a new idea, practice, or object due to their differences in individual innovativeness (Yi et al., 2006), one can assume, that different generations may differently contribute to creation of Society 5.0.

\section{Study Method}

Taking into consideration the theoretical aspects of individual innovativeness and rethinking on generational diversity, the main research question was formulated: How does individual innovativeness differ across generations?

An explorative research tradition was selected because in Lithuania there is a lack of studies were would be investigated how does individual innovativeness differ across generations. Moreover, to date, academic research on generational differences has been descriptive rather than explanatory (Joshi et al., 2011). An explorative study enabled not only to test the research tools developed by the leading authors of the field in Lithuania but also allowed to discuss how different generations considering the expression of their innovativeness can contribute to creation the Society 5.0 in Lithuania.

In prior to this study were raised several hypothetical questions based on the view that not all the generational characteristics can be applicable to all individuals of this generation. Education (Roffeei et al., 2017), gender (Alsos et al., 2013), and employment and the position occupied at work may also be influential factors (Yigit \& Aksay, 2015) when analysing the features of different generations. Moreover, knowledge of the features of different generations is very important while "organisations that work proactively to address the different generations will reap the benefits, while those that ignore the impact of the multigenerational workforce risk losing in the war for talent" (Bursch \& Kelly, 2014, p. 16). The hypothetical questions are following: Is a significant difference between the individual innovativeness among different generations across the individuals? Is a significant difference between the individual innovativeness among different generations according to the gender? Is a significant difference between the individual innovativeness among different generations according to the education? Is a significant difference between the individual innovativeness among different generations according to the occupied position at work?

The first part of the questionnaire includes the "Individual Innovativeness Scale" developed by Hurt, Joseph and Cook (1977). The "Individual Innovativeness Scale" consists of 20 items. The items constituting the Individual Innovativeness scale of the measurement tool were five-point Likert-type items (strongly agree -5 , agree -4 , neutral -3 , disagree -2 , strongly disagree -1 ). The scale consists of one dimension. 12 of the scale items are positive (items 1, 2, 3, 5, 8, 9, 11, 12, 14, 16, 18 and 19), whereas 8 are negative (items 4, 6, 7, 10, 13, 15, 17 and 20). According to the scores calculated based on the scale, individuals who score above 80 are considered "Innovators," between 69-80 are "Early Adopters", between 57-68 are "Early Majority", between 46-56 are "Late Majority", and below 46 are "Laggards" (Hurt et al., 1977). The second part of the questionnaire includes demographic information of the participants. The information allowed identification of generations, i.e. to attribute each individual to one of the four generations. An individual is assigned to a generation, based on the Theory of Generations by the date of birth (Howe \& Strauss, 2000).

The Society 5.0 is a forthcoming phenomenon in Lithuania. Therefore, the extent of the Society 5.0 is not 
validated yet in Lithuania. It does not give the possibility to select the statistically valid number of Society 5.0 respondents for the study, so it was decided the number of them to select based on the known data related to this research.

According to EUROSTAT's (2018) report, in 2018 annual population in Lithuania was 2808901 citizens. Based on the resident population age structure of the Republic of Lithuania, at the beginning of the year 2018, the workingage population, aged 15 (Generation $\mathrm{Z}$ ) to 64 (the Baby Boomers), comprised 65.4 per cent of all the population of Lithuania.

Since the population size $(\mathrm{N}=1837021)$ is known, the Yamane formula was applied to determine the sample size of the survey (Singh \& Masuku, 2014, p. 15):

$$
n=\frac{N}{\left(1+N \cdot e^{2}\right)}
$$

where $\mathrm{n}$ - corrected sample size, $\mathrm{N}$ - population size, and $\mathrm{e}-$ Margin of error $(\mathrm{MoE})$ (in this research $\mathrm{e}=0.053$ ).

$$
\begin{gathered}
n=\frac{1837021}{\left(1+1837021 \cdot 0.053^{2}\right)}=\frac{1837021}{5161.191989} \\
=355.9296 \sim 356 .
\end{gathered}
$$

For the study 356 representatives of four generations were selected. Each participant was attributed to one of the four generations (the Baby Boomers Generation, Generation X, Generation Y, Generation Z). Participants were attributed to the particular generation based on the recommendations provided by the Theory of Generations (Howe \& Strauss, 2000). According to the date of birth, respondents were attributed to four different generations: $9.55 \%$ as the Baby Boomers $(n=34), 35.96 \%$ the Generation X $(n=128), 28.09 \%$ the Generation Y $(n=100)$, $26.40 \%$ the Generation $\mathrm{Z}(\mathrm{n}=94)$. Distribution of the sample based on the test results of the individual innovativeness is presented in the Table 1.

\begin{tabular}{|c|c|c|c|}
\hline Categories of Individual Innovativeness & $\begin{array}{c}\text { Individual innovativeness classification } \\
\text { and scores }\end{array}$ & $\begin{array}{c}\text { Frequency } \\
\text { n }\end{array}$ & $\%$ of Total Sum \\
\hline Innovators & $>80$ & 30 & 8.43 \\
\hline Early Adopters & $69-80$ & 120 & 33.71 \\
\hline Early Majority Adopters & $57-68$ & 161 & 45.22 \\
\hline Late Majority Adopters & $46-56$ & 29 & 8.15 \\
\hline Laggards & $<46$ & 16 & 4.49 \\
\hline Total & & 356 & 100.00 \\
\hline
\end{tabular}

Individual Innovativeness of Participants

Table 1

Field study has started in January 2018 and ended in July of 2018. The on-line survey was used. Each respondent participated in this survey on a voluntary basis. The participation in the survey was their personal decision. Participants of the research were acquainted with the content of the research and gave verbal consent. Participants in the research were volunteers and were provided with information on the objectives, progress and presentation of the results of the research. During the research, the laws and conventions, protecting human rights were respected, privacy and anonymity of the subjects were not violated.

The data obtained from the research was analysed by the statistical software package SPSS 22.0.

Three methods were used for data analysis. The Hierarchical Cluster analysis, Multidimensional scaling (ALSCAL) and the CATREG - Regression for Categorical Data.

The Hierarchical Cluster analysis was used for classification of interaction cases between individual innovativeness and generation. In total 12 clusters were extracted. All of them are meaningful and can be used in the future to describe the difference between the types of individual innovativeness according to the different generations.

For the hierarchical clustering the Ward's method was used and interval was measured using the Squared Euclidian distance.

The Multidimensional scaling (ALSCAL) was used for the positioning of the interactions between individual innovativeness and four generations. This method is used with interval measure Squared Euclidian distance and using the scaling model Euclidian distance. The use of this method allowed to develop the taxonomy for an interaction between the types of Individual innovativeness and the Generations (see Figure 1).
In addition to the classification, the CATREG Regression for Categorical Data was used to test the possible relationship between the individual innovativeness of different generations and the external variables (occupation, gender, education, and position at work). Were found that there is no significant relation between the individual innovativeness of different generations and the gender, education, and position at work.

The results of positive test of the relationship between the individual innovativeness of different generations and the occupation is presented in Table $3(a, b, c)$. All the statistics can be considered as significant.

\section{Results}

The clustering of the individual innovativeness of different generations revealed relatively large dispersion according the both research attributes the types of individual innovativeness and respondents that belong to a certain generation. Before the study the different theoretical and empirical insights were listed and only some of them was strict in relating the strong individual innovativeness to the generation X (Yigit \& Aksay, 2015). In our case the study confirmed that among the representatives is seen relatively large dispersion of the attributes of the studied phenomenon (see Figure 1).

This allow to state that the certain generation consists out of people who has different attitudes to the individual innovativeness and possibly might play different roles in it by making their individual impact on creation of Society 5.0 in Lithuania. Nevertheless, it can be seen that each generation has a certain profile of individual innovativeness types. 
Asta Savaneviciene, Gita Statnicke, Sigitas Vaitkevicius. Individual Innovativeness of Different Generations in the ...

Here is possible to state hypothetically, that the distribution presented in Figure 1 might be splited into three levels according to the extent of the individual innovation. It could be the creators (less than -1 on the scale of innovation), developers (from the 1 to -1 on the scale of innovation) and supporters (more than 1 on the scale of innovation). All these three levels are important for the development of the innovativeness. Creators considering the typology of Rogers (2010) are associated with Innovators. Developers cluster covers the Early Adopters and Early Majority Adopters, and supporters are related with Late Majority Adopters and Laggards. Due to the small number of respondents reflecting the type of Laggards, they were added to Late Majority Adopters type.

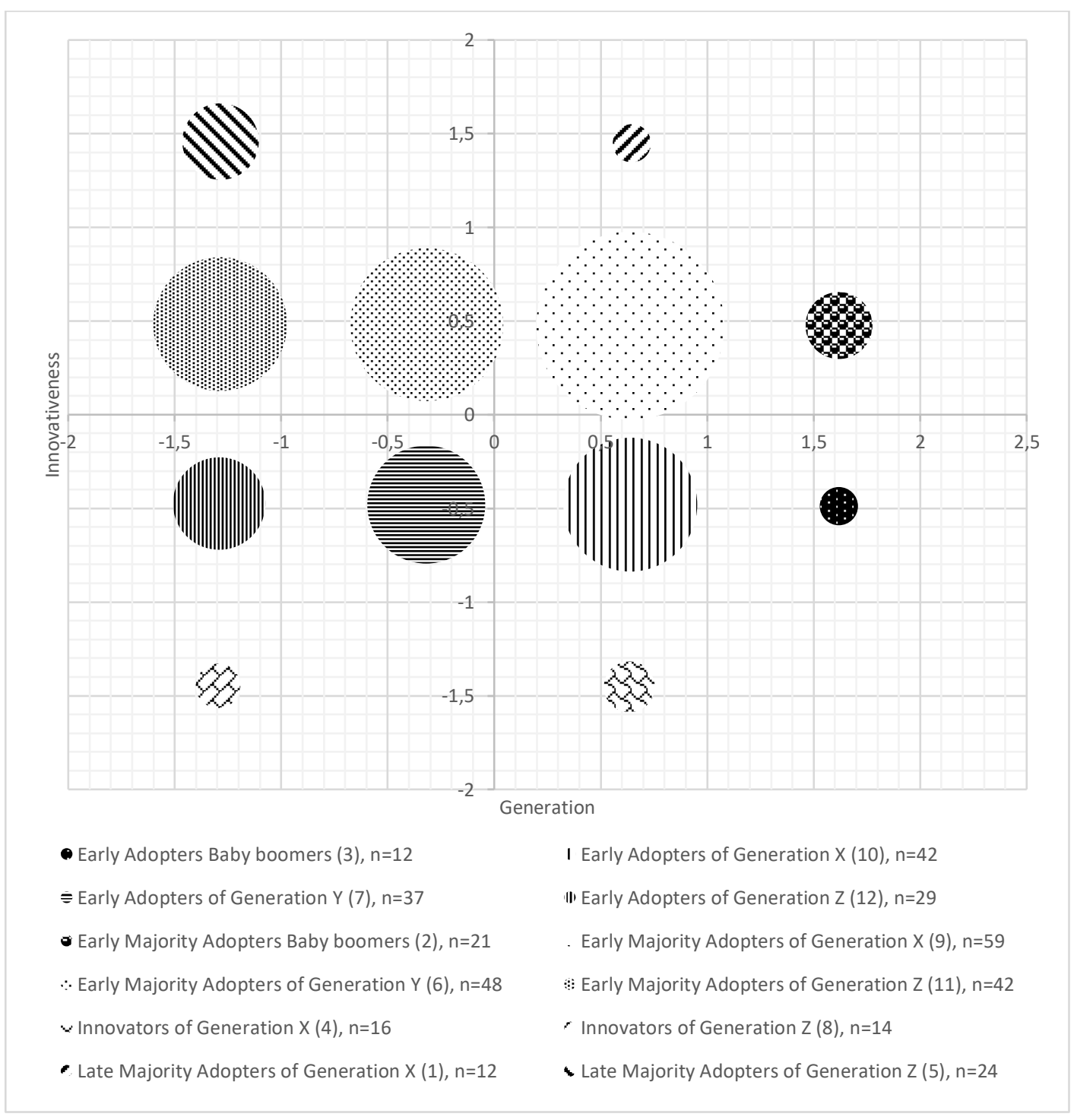

Figure 1. The Taxonomy of Individual Innovativeness Clusters Considering the Generations in Lithuania

The fact that the model of the distribution presented in Figure 1 does not fully reflect the full pattern of the individual innovativeness can be seen from the more indepth analysis of the phenomenon of individual innovativeness among the generations Baby Boomers, X, Y, and $\mathrm{Z}$ (see Table 2). More in-depth analysis explored that for example the first cluster which is named as a Late Majority Adopters of Generation X not only contain the representatives of Generation $X$ but also and the representatives of Baby Boomers. The category Generation $\mathrm{X}$ was applied because the Generation $\mathrm{X}$ was dominant in this cluster. Same was done with selecting the leading concept for innovativeness in this cluster. 
Clusters of the Individual Innovativeness Pattern of the Generations

\begin{tabular}{|c|c|c|c|c|c|c|c|c|c|c|c|c|c|}
\hline \multicolumn{2}{|c|}{ Cluster: } & $\begin{array}{l}\text { Late } \\
\text { Majority } \\
\text { Adopters } \\
\text { of } \\
\text { Generation } \\
\mathrm{X}(1), \mathrm{n}=12\end{array}$ & $\begin{array}{l}\text { Early } \\
\text { Majority } \\
\text { Adopters } \\
\text { Baby } \\
\text { boomers } \\
(2), n=21\end{array}$ & $\begin{array}{l}\text { Early } \\
\text { Adopters } \\
\text { Baby } \\
\text { boomers } \\
(3), n=12\end{array}$ & $\begin{array}{l}\text { Innovators } \\
\text { of } \\
\text { Generation } \\
\mathrm{X}(4) \\
\mathrm{n}=16\end{array}$ & $\begin{array}{l}\text { Late } \\
\text { Majority } \\
\text { Adopters } \\
\text { of } \\
\text { Generation } \\
\mathrm{Z}(5), \mathrm{n}=24\end{array}$ & $\begin{array}{l}\text { Early } \\
\text { Majority } \\
\text { Adopters } \\
\text { of } \\
\text { Generation } \\
\mathrm{Y}(6), \\
\mathrm{n}=48\end{array}$ & $\begin{array}{l}\text { Early } \\
\text { Adopters } \\
\text { of } \\
\text { Generation } \\
\text { Y (7), } \\
\mathrm{n}=37\end{array}$ & $\begin{array}{l}\text { Innovators } \\
\text { of } \\
\text { Generation } \\
Z(8), n=14\end{array}$ & $\begin{array}{l}\text { Early } \\
\text { Majority } \\
\text { Adopters } \\
\text { of } \\
\text { Generation } \\
\mathrm{X}(9), \\
\mathrm{n}=59\end{array}$ & $\begin{array}{l}\text { Early } \\
\text { Adopters } \\
\text { of } \\
\text { Generation } \\
X(10), \\
\mathrm{n}=42\end{array}$ & $\begin{array}{l}\text { Early } \\
\text { Majority } \\
\text { Adopters } \\
\text { of } \\
\text { Generation } \\
\mathrm{Z}(11) \\
\mathrm{n}=42\end{array}$ & $\begin{array}{l}\text { Early } \\
\text { Adopters } \\
\text { of } \\
\text { Generation } \\
\mathrm{Z}(12), \\
\mathrm{n}=29\end{array}$ \\
\hline \multirow{4}{*}{ : } & \multirow{4}{*}{3} & $\begin{array}{c}\text { Baby } \\
\text { Boomers }\end{array}$ & $\begin{array}{c}\text { Baby } \\
\text { Boomer } \\
\text { s }\end{array}$ & $\begin{array}{c}\text { Baby } \\
\text { Boomer } \\
\text { s }\end{array}$ & \multirow{4}{*}{$\begin{array}{c}\text { Baby } \\
\text { Boomers } \\
\text { Generatio } \\
\text { n X } \\
\end{array}$} & & & & & \multirow{4}{*}{$\begin{array}{c}\text { Generatio } \\
\text { n X }\end{array}$} & \multirow{4}{*}{$\begin{array}{c}\text { Generatio } \\
\text { n X }\end{array}$} & \multirow[b]{4}{*}{$\begin{array}{c}\text { Generatio } \\
\text { n Z }\end{array}$} & \multirow[b]{4}{*}{$\begin{array}{c}\text { Generatio } \\
\mathrm{n} Z\end{array}$} \\
\hline & & $\begin{array}{c}\text { Generatio } \\
\mathrm{n} \mathrm{X}\end{array}$ & & & & & & & & & & & \\
\hline & & & & & & \multirow{2}{*}{$\begin{array}{c}\text { Generatio } \\
\text { n Y } \\
\text { Generatio } \\
\text { n Z }\end{array}$} & $\begin{array}{c}\text { Generatio } \\
\text { n Y }\end{array}$ & $\begin{array}{c}\text { Generatio } \\
\text { n Y }\end{array}$ & \multirow{2}{*}{$\begin{array}{c}\text { Generatio } \\
\text { n Y } \\
\text { Generatio } \\
\text { n Z }\end{array}$} & & & & \\
\hline & & & & & & & & & & & & & \\
\hline \multirow{5}{*}{ 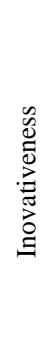 } & 1 & Laggards & & & & Laggards & & & & & & & \\
\hline & 2 & $\begin{array}{c}\text { Late } \\
\text { Majority } \\
\text { Adopters }\end{array}$ & & & & $\begin{array}{c}\text { Late } \\
\text { Majority } \\
\text { Adopters }\end{array}$ & & & & & & & \\
\hline & 3 & & $\begin{array}{c}\text { Early } \\
\text { Majority } \\
\text { Adopter } \\
\text { s }\end{array}$ & & & & $\begin{array}{c}\text { Early } \\
\text { Majority } \\
\text { Adopters }\end{array}$ & & & \multirow[t]{2}{*}{$\begin{array}{c}\text { Early } \\
\text { Majority } \\
\text { Adopters }\end{array}$} & & $\begin{array}{l}\text { Early } \\
\text { Majority } \\
\text { Adopters }\end{array}$ & \\
\hline & 4 & & & $\begin{array}{c}\text { Early } \\
\text { Adopter } \\
\text { s } \\
\end{array}$ & & & & $\begin{array}{c}\text { Early } \\
\text { Adopters }\end{array}$ & & & $\begin{array}{c}\text { Early } \\
\text { Adopters }\end{array}$ & & $\begin{array}{l}\text { Early } \\
\text { Adopters }\end{array}$ \\
\hline & 5 & & & & Innovators & & & & Innovators & & & & \\
\hline
\end{tabular}

From the Table 2 also can be seen that except the Generation $\mathrm{X}$ all other generations had the representatives of the all types of innovativeness. Only the Generation $\mathrm{X}$ has no Laggards. However, the study was an explorative. It cannot be stated that the absence of the Laggards among the Generation $\mathrm{X}$ representatives in the sample is a confident finding significantly describing an exclusive pattern of the Generation X.

The study results also presented the evidences that the hypothetical question about the interdependence between the construct of individual innovativeness among different generations and the external factors like occupation, gender, education and occupied position at work also can be tested.

The results of an explorative test revealed that the significant interdependence between the individual innovativeness of different generations and the occupation exist. In-depth analysis of this finding explored that the unemployed representatives were less innovative then those who was occupied (Table 3).

Table 3

3 CATREG Model of the Relationship between the Individual Innovativeness of Different Generations and the Occupation
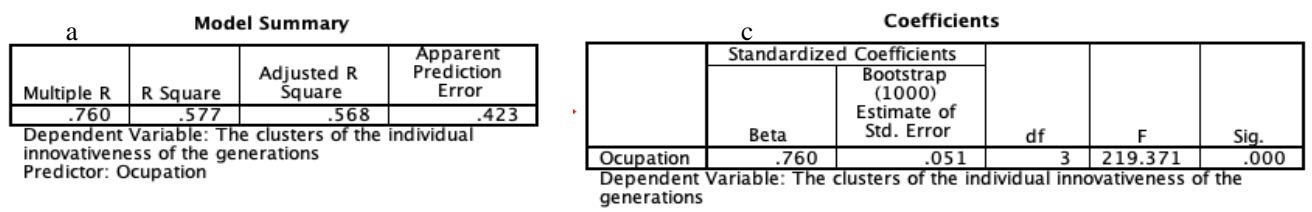

\begin{tabular}{|c|c|c|c|c|c|}
\hline \multicolumn{6}{|c|}{ ANOVA } \\
\hline b & $\begin{array}{l}\text { Sum of } \\
\text { Squares }\end{array}$ & $\mathrm{df}$ & Mean Square & $\mathrm{F}$ & \\
\hline Regression & 79.645 & 3 & 26.548 & 60.963 & .000 \\
\hline Residual & 58.355 & 134 & .435 & & \\
\hline Total & 138.000 & 137 & & & \\
\hline
\end{tabular}

Considering other external variables (gender, education, and position at work) was found that there is no significant relation between the individual innovativeness of different generations and the gender, education, and position at work.

\section{Discussion}

Despite some scientists have argued that the magnitude and importance of generational differences is overstated in research (Costanza et al., 2012; Trzesniewski \& Donnellan, 2010), and they are more myth than reality (Giancola, 2006) this paper follows the approach that the values form in childhood and persist throughout all life (Hansen \& Leuty, 2012). Considering this approach values are stable enough, and it is unlikely that they will change with advancing age (Pyoria et al., 2017). This creates a presumption that the values of people born at a certain time are formed in the context of the social, economic and political events taking place at the time and varies across generations. Although Rogers (2010) studies have shown a different distribution of individual innovativeness' types across generations in the investigated population. The subsequent studies (Yigit \& Aksay, 2015) showed that there is a difference of individual innovativeness between the participants coming from the Generations $\mathrm{X}$ and $\mathrm{Y}$. 
Asta Savaneviciene, Gita Statnicke, Sigitas Vaitkevicius. Individual Innovativeness of Different Generations in the ...

The purpose of the paper was to disclose how does individual innovativeness differ across generations in Lithuania and to discuss how they can contribute to creation of Society 5.0 in Lithuania. It was presumed that the certain generation consists out of people who has different attitudes to the individual innovativeness and possibly might play different roles in it by making their individual impact on creation of Super Smart Society in Lithuania.

The study results revealed three main clusters that cover people from different generations with different types of individual innovativeness: creators, developers and supporters.

Creators considering the typology of Rogers (2010) are associated with Innovators, people who are very willing to take risks (Rogers, 2010), are the first who create a new products and processes (Rogers, 2010; Wilson \& Stacey, 2002). Moreover, they are often the first who rise the new ideas. According to authors (Wilson et al., 2002; Rogers, 2010), Innovators usually comprise about 2-3\% of the population. Although exploratory does not rely on descriptive statistics, but rather focuses on cognition of phenomenon content, the survey results show that the cluster of innovators covers a small number of respondents $(8.5 \%)$ as well. However, all generations have creators and that suppose the creations of new ideas, regardless of the structure of the generations in the market.

Developers cluster covers the Early Adopters and Early Majority Adopters. According to several authors (Wilson et al., 2002; Rogers, 2010), Early Adopters usually comprise about 13-14 \%, and Early Majority Adopters usually comprise about $34 \%$ of the population. The study identified $33.71 \%$ of Early Adopters and $45.22 \%$ Early Majority Adopters. Both types were covered by all generations. Early Adopters are open to the change opportunities and are enthusiastic while adopting new ideas. Although Early Adopters are less likely to risk than innovators, but they are leaders in social systems using the latest technology or innovation in activities (Moore, 1999). Early Majority Adopters are seeking for security, they avoid changes and are unwilling to take risks until there is absolute clarity (Soffer, et al., 2010). Typically, they need to see the evidences that the innovation works before they are willing to adopt it. However, if they believe in the idea, they are willing to develop it further. In summary, it can be said that the representatives of this cluster are developers and adopters of the already generated ideas. Without these people, ideas would not be implemented in the practice.

Supporters are related with Late Majority Adopters and Laggards. According to authors (Wilson et al., 2002; Rogers, 2010), Late Majority Adopters usually comprise about $34 \%$ and Laggards usually comprise about $16 \%$ of the population. The study identified $8.15 \%$ of Late Adopters and $4.49 \%$ of Laggards. Late Majority Adopters are skeptical of change and will only adopt an innovation after it has been tried by the majority. According to Greenhalgh et al (2008) Late Majority Adopters adopt a new idea only when it becomes a well-known standard. The late majority are very suspicious and cautious about innovation, hardly adapting to innovation, accepting innovation only when they are convinced that they are in line with their interests. Laggards are bound by tradition and they are very skeptical of change. They tend to disapprove or even resist innovation if it is not necessary (Greenhalgh et al., 2008; Soffer et al.,
2010). Therefore, they can be no more than supporters of the already implemented ideas. They work hard then the idea is accepted and is ready for the overall use. However, supporters are a very important part of a population, they can be treated as a guarantee of stability, forcing more risk-oriented individuals to think and weigh not only the benefits of innovation but the possible disruptive consequences as well.

Except the Generation $\mathrm{X}$ all other generations had the representatives of the all types of innovativeness. Only the Generation X has no Laggards. However, the study was an explorative. It cannot be stated that the absence of the Laggards among the Generation $X$ representatives in the sample is a confident finding significantly describing an exclusive pattern of the Generation X. However, this result partly supports the results of Yigit and Aksay (2015) research which indicated that the Generation $\mathrm{X}$ is more innovative (p. 106).

Should be noted that all these three levels of individual innovativeness are important for forthcoming of Society 5.0 in Lithuania. This mix of different categories of individual innovativeness of different generations gives the synergy effect. However, should be noted that study in Lithuania revealed the greater focus on individual innovativeness in term that more respondents reflect the Innovators and Early Adopters types comparing to another topic-related research.

Nevertheless, due to various limitations in study design, the results should be interpreted with the care. This is an exploratory study. It cannot be stated that the study results based on the representatives in the sample is a confident by finding and significantly describing an the pattern of the society in Lithuania.

The forthcoming of Society 5.0 in Lithuania is driven by both objective reasons such as aging society and ITbased technology potential, enabling response of the demand of aging society.

\section{Conclusions}

The clustering of the individual innovativeness of different generations revealed relatively large dispersion according the both research attributes the types of individual innovativeness and respondents that belong to a certain generation. The study results revealed three main clusters that cover people from different generations with different types of individual innovativeness: creators, developers and supporters. Creators tend to risk, they generate new ideas, develop or are among the first to test new products and processes. Developers are those who develop the ideas or new products and processes that have been generated and implemented. Supporters are considered as a guarantee of stability, forcing more risk-oriented individuals to think and weigh not only the benefits of innovations but also their potentially harmful consequences. The findings revealed that except the Generation X all other generations had the representatives of the all types of innovativeness; greater focus on individual innovativeness in term that more respondents reflect the Innovators and Early Adopters types comparing to another topic-related research. All these three levels of individual innovativeness are important for the forthcoming of Society 5.0 in Lithuania, since only the synergy of all the representatives of individual innovativeness categories belonging to different generations 
can create optimal conditions and maintain a sufficient level of innovativeness for the development of the Super Smart Society in Lithuania.

While creating the of Society 5.0 in Lithuania, each generation is of importance, since it consists of people with different individual innovativeness and capable of playing different roles in it by making their individual impact on the process of formation of such a society. Generations are changing every 20 years and each generation is unique. The study showed that intergenerational exchange process in Lithuania can proceed smoothly while maintaining the same high level of individual innovativeness.

Taking into consideration the analysis of the context of the forthcoming (Society 5.0), the theoretical aspects of individual innovativeness and rethinking on generational diversity in the context of individual innovativeness, one can assume that individual innovativeness is one of the key factors for the development of a successful Super Smart Society in Europe. In the process of digital transformation of the society that brings reality together with the virtual world, the contribution of each generation is important to the development, implementation and use of innovation.

It is important that teams of different generations have innovators who are capable of generating innovations and early adopters who can deliver them to the public in the context of the of Society 5.0. However, the research has shown that the innovativeness of different generations (i.e. Categories of Individual Innovativeness) varies, so it can be seen that each other generation has more or less the same innovativeness features. This ensures the innovativeness and potential of society, which is a prerequisite for a wellunderstood formation of the of Society 5.0.

\section{References}

Aaltio, I., Mills, A. J., \& Mills, J. H. (2016) Disruptive demographics: Ageing, socio-economic change, challenges and potentialities. International Journal of Work Innovation, 1(4), 323-329.

Agars, M. D., Kaufman, J. C., \& Locke, T. R. (2008). Social influence and creativity in organizations: A multi-level lens for theory, research, and practice. Multi-level issues in creativity and innovation. Emerald Group Publishing Limited, 3-61. https://doi.org/10.1016/S1475-9144(07)00001-X

Agolla, J. E. (2018). Human Capital in the Smart Manufacturing and Industry 4.0 Revolution. Digital Transformation in Smart Manufacturing. InTech. https://doi.org/10.5772/intechopen. 73575

Alsos, A. G., Ljunggren, E., \& Hytti, U. (2013). Gender and innovation: state of the art and a research agenda. International Journal of gender and Entrepreneurship, 5(3), 236-256. https://doi.org/10.1108/IJGE-06-2013-0049

Anderson, N., De Dreu, C. KW., \& Nijstad, B. A. (2004). The routinization of innovation research: A constructively critical review of the state-of-the-science. Journal of organizational Behavior, 25(2), 147-173. https://doi.org/10.1002/job.236

Arsenault, P. M. (2004). Validating generational differences: A legitimate diversity and leadership issue. Leadership and Organization Development Journal, 25(2), 124-141. https://doi.org/10.1108/01437730410521813

Becton, J. B., Walker, H. J., \& Jones-Farmer, A. (2014). Generational differences in workplace behavior. Journal of Applied Social Psychology, 44.3, 175-189. https://doi.org/10.1111/jasp.12208

Blackburn, M., Alexander, J., Legan, J. D., \& Klabjan, D. (2017). Big Data and the Future of R\&D Management: The rise of big data and big data analytics will have significant implications for R\&D and innovation management in the next decade. Research-Technology Management, 60(5), 43-51. https://doi.org/10.1080/08956308.2017.1348135

Bursch, D., \& Kelly, K. (2014). Managing the multigenerational workplace. UNC Executive Development. Available from internet: $\quad$ http://www.kenan-flagler.unc.edu/ /media/Files/documents/executive-development/managing-themultigenerational-workplace-white-paper.pdf.

Caesar, L. D., \& Fei, J. (2018). Work-life balance. Managing Human Resources in the Shipping Industry. Routledge, 107128. https://doi.org/10.4324/9781315740027-7

Carrington, V., Rowsell, J., Priyadharshini, E., \& Westrup R. (Eds.). (2015). Generation Z: Zombies, Popular Culture and Educating Youth. Springer.

Costanza, D. P., Badger, J. M., Fraser, R. L., Severt, J. B., \& Gade, P. A. (2012). Generational differences in work-related attitudes: A meta-analysis. Journal of Business and Psychology, 27(4), 375-394. https://doi.org/10.1007/s10869-0129259-4

Dent, T. L., James, L., Beck, C., Vince, C., Mena, P., Johnson, R., Grant, J., \& Caletti, P. (2011). Investigating how motivation affects generation Y's relatedness in the workplace. Available from internet: http://seanlyons.ca/wpcontent/uploads/2012/01/Motivation-and-Relatedness.pdf.

Deyoe, R. H., \& Fox, T. L. (2012). Identifying strategies to minimize workplace conflict due to generational differences. Journal of Behavioral Studies in Business, 5, 1-27.

Distanont, A., \& Khongmalai, O. (2018). The role of innovation in creating a competitive advantage. Kasetsart Journal of Social Sciences, 2018, 1-7. https://doi.org/10.1016/j.kjss.2018.07.009 
Asta Savaneviciene, Gita Statnicke, Sigitas Vaitkevicius. Individual Innovativeness of Different Generations in the ...

Digital Economy and Society Index (DESI) 2018 Country Report Lithuania. 2018. Available from internet: http://ec.europa.eu/information_society/newsroom/image/document/2018-20/lt-desi_2018-countryprofile_eng_1990F9A0-C739-F21C-79A318D3DC596A07_52229.pdf.

Dries, N., Pepermans, R., \& De Kerpel, E. (2008). Exploring four generations' beliefs about career: Is "satisfied" the new "successful"? Journal of managerial Psychology, 23(8), 907-928. https://doi.org/10.1108/02683940810904394

Driving Europe's digital transformation. 2017. Strategic Innovation Agenda 2017-19. EIT Digital, Brussels, Belgium. Available from internet: https://www.eitdigital.eu/fileadmin/files/2016/publications/EIT-Digital_SIA_2017-19.pdf.

EUROSTAT (2018). Population structure and ageing. Available from internet: http://appsso.eurostat.ec.europa.eu/ nui/show.do?dataset=demo_gind\&lang=en.

Farrell, L., \& Hurt, A. C. (2014). Training the Millennial Generation: Implications for Organizational Climate. E Journal of Organizational Learning and Leadership, 12(1), 1-14.

Fukuyama, M. (2018). Society 5.0: Aiming for a New Human-Centered Society. Japan SPOTLIGHT, 47-50. Available from internet: https://www.jef.or.jp/journal/pdf/220th_Special_Article_02.pdf.

Geck, C. (2007). The generation Z connection: Teaching information literacy to the newest net generation. In: Rosenfeld, E, Loertscher, DV (eds) Toward a 21st-Century School Library Media Program. Plymouth: Scarecrow Press, $235-241$.

Giancola, F. (2006). The generation gap: More myth than reality. People and strategy, 29.4, 32.

Goncalves, J. A. F. (2015). Towards a broader understanding of generational diversity at work: methodological and empirical contributions from a multi-cultural study. PhD Thesis. Universidade De Lisboa, Lisbon, Portugal. Available from internet: http://hdl.handle.net/10451/23595.

Greenhalgh, T., Robert, G., Bate, P., Macfarlane, F., \& Kyriakidou, O. (2008). Diffusion of innovations in Health Service Organisations: a systematic literature review. Blackwell Publishing Ltd.

Grodent, F., \& Peere, I. (2013). Examining Managers' careers at the crossing of gender and age. Paper presented at 13th annual conference of EURAM (2013), Galatasaray University, Istanbul, Turkey, June 26-29, 2013. Available from internet: http://hdl.handle.net/2268/152378.

Hansen, J. C., \& Leuty, M. E. (2012). Work values across generations. Journal of Career Assessment, 20(1), 34-52. https://doi.org/10.1177/1069072711417163

Harayama, M. (2017). Society 5.0: Aiming for a New Human-Centered Society Japan's Science and Technology Policies for Addressing Global Social Challenges. Hitachi Review, 66(6), 556-557.

Hartman, J. B., \& Samra, Y. M. (2008). Impact of personal values and innovativeness on hedonic and utilitarian aspects of web use: An empirical study among United States teenagers. International Journal of Management, 25(1), $77-94$.

Hayashi, Sh. (2017). Remarks on Special Issue on New Materials. Nippon steel and sumitomo metal technical report, 117 (2017-12), 1-2.

Hillman, D. R. (2014). Understanding multigenerational work-value conflict resolution. Journal of Workplace Behavioral Health, 29(3), 240-257. https://doi.org/10.1080/15555240.2014.933961

Howe, N., \& Strauss, W. (2000). Millennials rising: The next great generation. Vintage Books, New York, USA.

Huang, Y. K., \& Chen, J. Sh. (2009). Information synergy as the catalyst between information technology capability and innovativeness: Empirical evidence from the financial service sector. Information Research, 14(1), 380-394.

Hur, H. J., Lee, H. K., \& Choo, H. J. (2017). Understanding usage intention in innovative mobile app service: Comparison between millennial and mature consumers. Computers in Human Behavior, 73, 353-361. https://doi.org/10.10 16/j.chb.2017.03.051

Hurt, H. Th., Joseph, K., \& Cook, Ch. D. (1977). Scales for the measurement of innovativeness. Human Communication Research, 4(1), 58-65. https://doi.org/10.1111/j.1468-2958.1977.tb00597.x

Ikiz, F. E., \& Asici, E. (2017). The Relationship between Individual Innovativeness and Psychological Well-Being: The Example of Turkish Counselor Trainees. International Journal of Progressive Education, 13(1), 52-63.

Inglehart, R. F. (2008). Changing values among Western Publics from 1970 to 2006, West European Politics, 31(1-2), 130146. https://doi.org/10.1080/01402380701834747

Ionescu, A., \& Dumitru, N. R. (2015). The role of innovation in creating the company's competitive advantage. Ecoforum Journal, 4(1), 99-104.

Jackson, J. D., Mun, Y. Y., \& Park, J. S. (2013). An empirical test of three mediation models for the relationship between personal innovativeness and user acceptance of technology. Information and Management, 50(4), 154-161. https://doi.org/10.1016/j.im.2013.02.006 
Jin, Ch. H. (2013). The effects of individual innovativeness on users' adoption of Internet content filtering software and attitudes toward children's Internet use. Computers in Human Behavior, 29(5), 1904-1916. https://doi.org/10.101 6/j.chb.2013.03.009

Joshi, A., Dencker, J. C., \& Franz, G. (2011). Generations in organizations. Research in Organizational Behavior, 31, 177205. https://doi.org/10.1016/j.riob.2011.10.002

Keidanren Annual Report 2018. Japan Business Federation. Available from internet: http://www.keidanren.or.jp/en/profile/ Keidanren_Annual_Report2018.pdf.

Kilicer, K., Bardakci, S., \& Arpaci, I. (2018). Investigation of Emerging Technology Usage Characteristics as Predictors of Innovativeness. Contemporary Educational Technology, 9(3), 225-245. https://doi.org/10.30935/cet.444100

Leonard-Barton, D., \& Deschamps, I. (1988). Managerial influence in the implementation of new technology. Management Science, 34(10), 1252-1265. https://doi.org/10.1287/mnsc.34.10.1252

Levy, Ch., \& Wong, D. (2014). Towards a smart society. The Big Innovation Centre (The Work Foundation and Lancaster University), London. Available from internet: http://www.biginnovationcentre.com/media/uploads/pdf/ 1425646824_0714590001425646824.pdf.

Lewis, R. A. (2015). Generation Y at work: insight from experiences in the hotel sector. International Journal of Business and Management, 3(1), 1-17. https://doi.org/10.20472/BM.2015.3.1.001

Lithuania's progress strategy "Lithuania 2030". (2012). Available from internet: https://rio.jrc.ec.europa.eu/en/library/national -progress-strategy-lithuania-2030.

Lu, J., Liu, Ch., Yu, Ch. Sh., \& Wang, K. (2008). Determinants of accepting wireless mobile data services in China. Information and Management, 45(1), 52-64. https://doi.org/10.1016/j.im.2007.11.002

Lu, J., Yao, J. E., \& Yu, Ch. Sh. (2005). Personal innovativeness, social influences and adoption of wireless Internet services via mobile technology. The Journal of Strategic Information Systems, 14(3), 245-268. https://doi.org/10.10 16/j.jsis.2005.07.003

Lyons, S. T., Schweitzer, L., \& Ng, E. SW. (2015). How have careers changed? An investigation of changing career patterns across four generations. Journal of Managerial Psychology, 30.1, 8-21. https://doi.org/10.1108/JMP-07-2014-0210

Macky, K., Gardner, D., \& Forsyth, St. (2008). Generational differences at work; introduction and overview. Journal of Managerial Psychology, 23(8), 857-861. https://doi.org/10.1108/02683940810904358

Mannheim, K. (1952). The Problem of Generations. In P. Kecskemeti (Ed.), Essays on the sociology of knowledge (pp. 276320). Routledge and Kegan Paul, London.

Martins, C. B. M. J. (2018). The Individual innovativeness theory: a framework to investigate teachers' views on technology. ICICTE 2018 Proceedings, 360-370.

Mitleton-Kelly, E. (Eds.). (2003). Complex Systems and Evolutionary Perspectives on Organisations: The Application of Complexity Theory to Organisations. Oxford: Elsevier Science Ltd., UK.

Moore, G. A. (1999). Crossing the Chasm: Marketing and selling high-tech products to mainstream customers. HarperCollins Publishers Pty. Ltd, Australia.

Moschis, G. P., Ferguson, J. L., \& Zhu, M. (2011). Mature consumers' selection of apparel and footwear brands and department stores. International Journal of Retail and Distribution Management, 39(10), 785-801. https://doi.org/10.1 108/09590551111162266

Neves, B. B., \& Vetere, F. (2019). Ageing and Emerging Digital Technologies. Ageing and Digital Technology, 1-14. https://doi.org/10.1007/978-981-13-3693-5_1

Nichols, Th., \& Wright, M. (2018). Generational differences: understanding and exploring generation Z. 2017-2018 Officers President President-Elect: $177-185$.

Pirvu, B. C., \& Zamfirescu, C. B. (2017). Smart factory in the context of 4th Industrial revolution: challenges and opportunities for Romania. In IOP Conference Series: Materials Science and Engineering, 227(1), 1-10. https://doi.org/10.1088/1757-899X/227/1/012094

Pyoria, P., Ojala, S., Saari, T., \& Jarvinen, K. M. (2017). The Millennial Generation: A New Breed of Labour? SAGE Open, 2017(1-3), 1-14. https://doi.org/10.1177/2158244017697158

Roffeei, S. H. M., Kamarulzaman, Y., \& Yusop, F. D. (2017). Inculcating innovative behaviour among students: Determinants of innovation culture in Malaysian higher education. MOJEM: Malaysian Online Journal of Educational Management, 5(4), 1-17. https://doi.org/10.22452/mojem.vol5no4.1

Roberts, B. W., Edmonds, G., \& Grijalva, E. (2010). It is developmental me, not generation me: Developmental changes are more important than generational changes in narcissism - Commentary on Trzesniewski \& Donnellan (2010). Perspectives on Psychological Science, 5(1), 97-102. https://doi.org/10.1177/1745691609357019 
Asta Savaneviciene, Gita Statnicke, Sigitas Vaitkevicius. Individual Innovativeness of Different Generations in the ...

Rogers, E. M. (2010). Diffusion of innovations. The Free Press, New York, USA.

Rudolph, C. W., Rauvola, R. S., \& Zacher, H. (2018). Leadership and generations at work: a critical review. The Leadership Quarterly, 29(1), 44-57. https://doi.org/10.1016/j.leaqua.2017.09.004

Serpanos, D. (2018). The Cyber-Physical Systems Revolution. Computer, 51(3), 70-73. https://doi.org/10.1109/MC. 2018.1731058

Shiroishi, Y., Uchiyama, K., \& Suzuki, N. (2018). Society 5.0: For Human Security and Well-Being. Computer, 51(7), 9195. https://doi.org/10.1109/MC.2018.3011041

Singh, A. S., \& Masuku, M. B. (2014). Sampling techniques \& determination of sample size in applied statistics research: An overview. International Journal of Economics, Commerce and Management, 2(11), 1-22.

Sjodin, D. R., Parida, V., Leksell, M., \& Petrovic, A. (2018). Smart Factory Implementation and Process Innovation: A Preliminary Maturity Model for Leveraging Digitalization in Manufacturing Moving to smart factories presents specific challenges that can be addressed through a structured approach focused on people, processes, and technologies. Research-Technology Management, 61(5), 22-31. https://doi.org/10.1080/08956308.2018.1471277

Skiba, D. J., \& Barton, A. J. (2006). Adapting your teaching to accommodate the Net generation of learners. Online Journal of Issues in Nursing, 11(2), 15.

Soffer, T., Nachmias, R., \& Ram, J. (2010). Diffusion of web supported instruction in higher education - The Case of TelAviv University. Journal of Educational Technology and Society, 13(3), 212-223.

Srinivasan, V. (2012). Multi generations in the workforce: Building collaboration. IIMB Management Review, 24(1), 48-66. https://doi.org/10.1016/j.iimb.2012.01.004

9th EU-Japan Science Policy Forum. (2018). Available from internet: https://eeas.europa.eu/delegations/japan/52294/9th-eujapan-science-policy-forum-6-october-2018-and-15th-sts-forum-7-9-october-2018_en.

Thakur, R., Angriawan, A., \& Summey, J. H. (2016). Technological opinion leadership: The role of personal innovativeness, gadget love, and technological innovativeness. Journal of Business Research, 69(8), $2764-2773$. https://doi.org/10.1016/j.jbusres.2015.11.012

Trzesniewski, K. H., \& Donnellan, M. B. (2010). Rethinking "Generation Me": A study of cohort effects from $1976-2006$. Perspectives on Psychological Science, 5(1), 58-75. https://doi.org/10.1177/1745691609356789

Twenge, J. M., Campbell, S. M., Hoffman, B. J., \& Lance, CH. E. (2010). Generational differences in work values: Leisure and extrinsic values increasing, social and intrinsic values decreasing. Journal of management, 36(5), 1117-1142. https://doi.org/10.1177/0149206309352246

Van Rijnsoever, F. J., \& Donders, A. R. T. (2009). The effect of innovativeness on different levels of technology adoption. Journal of the American Society for Information Science and Technology, 60(5), 984-996. https://doi.org/10.10 02/asi.21029

Wilson, B. G., Sherry, L., Dobrovolny, J., Batty, M., \& Ryder, M. (2002). Adoption factors and processes. In H. H. Adelsberger, B. Collis and J. M. Pawlowski (Eds.), Handbook on information technologies for education and training (pp. 293-307). Springer, Berlin, Heidelberg. https://doi.org/10.1007/978-3-662-07682-8_18

Yi, M. Y., Fiedler, K. D., \& Park, J. S. (2006). Understanding the role of individual innovativeness in the acceptance of itbased innovations: Comparative analyses of models and measures. Decision Sciences, 37(3), 393-426. https://doi.org/10.1111/j.1540-5414.2006.00132.x

Yigit, S., \& Aksay, K. (2015). A comparison between Generation X and Generation Y in terms of individual innovativeness behavior: the case of Turkish health professionals. International Journal of Business Administration, 6(2), 106-117. https://doi.org/10.5430/ijba.v6n2p106

Yuan, F., \& Woodman, R. W. (2010). Innovative behavior in the workplace: The role of performance and image outcome expectations. Academic Management Journal, 53(2), 323-342. https://doi.org/10.5465/amj.2010.49388995

Yuksel, I. (2015). Rogers' diffusion of innovation model in action: Individual innovativeness profiles of pre-service teachers in Turkey. Croatian Journal of Education: Hrvatski casopis za odgoj i obrazovanje, 17(2), 507-534. https://doi.org/10.15516/cje.v17i2.871

The article has been reviewed.

Received in February 2019; accepted in April 2019. 